\title{
The Relationship Between Soil-transmitted Helminth Infections and Clean and Healthy Living Behavior
}

\author{
Anifa Chofsoh Zuchaliya ${ }^{1 *}$, Yulia Sari ${ }^{2}$, Sigit Setyawan ${ }^{2}$, Yusuf Ari Mashuri ${ }^{2}$ \\ ${ }^{1}$ Student of Undergraduate Medical Education Program, Faculty of Medicine, Sebelas Maret \\ University \\ ${ }^{2}$ Faculty of Medicine, Sebelas Maret University, Indonesia
}

*corresponding author, e-mail: anifachofsoh@student.uns.ac.id

Received: 28/11/2020; published 21/08/2021

\begin{abstract}
Background: Soil-transmitted Helminth (STH) are nematodes that can infect humans through direct contact with soil due to poor hygiene behavior. School-age children are the most susceptible to the infection. The clinical symptoms of STH infection are usually asymptomatic. However, it can affect the quality of life of the infected. This study aims to analyze the relationship between STH infection with clean and healthy living behavior; Method: This study takes the form of analytic observational research with a cross-sectional approach. The sampling technique used was the total sampling method with subjects of 132 students of Sekolah Dasar (SD) 1 Talakbroto, SD 1 Kedunglengkong, and SD Wates, Simo, Boyolali. The data were obtained from the results of the students' clean and healthy living behavior questionnaire and the examination of stool samples using the Kato Katz technique. Data were presented in a categorical form and analyzed using the chi-square method.; Results: There were 15 students $(11 \%)$ infected by STH from 132 subjects studied. Based on the chi-square test, the p-value of STH infection and clean and healthy living behavior was $0.043(p<0,05)$; Conclusion: There is a significant relationship between STH infection with clean and healthy living behavior.
\end{abstract}

Keywords: Soil-transmitted Helminths (STH); Clean and Healthy Living Behavior; School age children

This is an open access article under the CC-BY-SA license.

1. Introduction

Soil-transmitted Helminth (STH) infections are among the infections that cause health problem in Indonesia [1]. STH infection is caused by Ascaris lumbricoides, hookworm (Ancylostoma duodenale and Necator americanus), and Trichuris trichiura [2]. About 1.5 billion people in the world are infected with one of the STH species [3]. The highest STH infection rate occurs in school-age children. There were 613 million school-age children across tropical and subtropical countries who were at risk of being infected by STH [2].

The prevalence of STH infection in Indonesia ranges from $2.5 \%$ to $62 \%$ [1]. Until now, worm infections data in Indonesia have not been integrated in all provinces. Only few provinces in Indonesia have definite data on worm infections according to sex and age. Central Java Province and Boyolali Regency are among the regions that do not yet have the data regarding the incidence of worm infections in each district [4].

The risk factors for STH infection are closely related to clean and healthy living behavior [5]. Clean and Healthy Living Behavior refers to the daily behavior that involves water, sanitation and hygiene [6]. STH infection is transmitted by oral transmission through food contamination, contaminated hands, and direct skin penetration (in hookworm species) [7]. The factors that can reduce STH infection are water quality [8], hygienic habits of hand washing [5], and habit of wearing footwear [9]. Thus, the habit of maintaining hygiene through clean and healthy living behavior is an important factor in breaking the chain of infection transmission [7]. 
There is a significant biological correlation between sanitation and STH infection, including the habit of open defecation. Children who defecate in latrines with poor hygiene will cause the soil to be contaminated by worm eggs. STH infection can be transmitted through hand contamination and then ingestion due to not washing hands before eating and after defecating [5].

STH infection is closely related to the habit of walking barefoot on the ground. This habit can be a factor in the transmission of Ancylostoma duodenale and Necator americanus worm infections due to transmission through skin penetration $[9,10]$. STH infection can cause intestinal manifestations, resulting in various problems in the digestive tract such as diarrhea, cramps, abdominal pain, and malnutrition due to the poor absorption of nutrients $[10,11]$. Severe infection can cause intestinal obstruction [11]. In addition, hookworm and Trichuris trichiura infection can cause blood loss and anemia [1214].

School-age children are the most susceptible group to worm infections because at this age they do plenty of activities in contact with the soil. STH infection in school-age children can cause intestinal inflammation $[11,17]$ and reduce the nutritional intake and protein energy, which can cause growth disruption, cognitive impairment [15], intelligence [16], and severe conditions in children when exposed to other infections [17].

Simo Sub-district is located in a lowland area, and the area largely consists of fields and rice fields. The majority of the population works as farmers and laborers [19]. Simo Sub-district is in the third lowest rank $(60.25 \%)$ of households with clean and healthy living behavior or Perilaku Hidup Bersih dan Sehat (PHBS) according to the Boyolali Regency and Community Health Center year 2018 [20]. This study aims to examine the relationship between STH infection and clean and healthy living behavior at Sekolah Dasar (SD) 1 Kedunglengkong, SD 1 Talakbroto, and SD Wates, in Simo Sub-district, Boyolali Regency.

\section{Method}

This takes the form of analytic observational research with cross sectional approach. The variables in this study were STH infection and clean and healthy living behavior. Data were presented categorically. STH infections were categorized into positive and negative infections. The clean and healthy living behavior consists of 4 factors, namely the habit of handwashing, the habit of wearing footwear, having a clean latrine, and having a clean water source. Each was given a score of 1 . Subjects with the 4 factors were categorized as having clean and healthy living behavior. On the contrary, subjects with none or only one factor were considered as having poor clean and healthy living behaviors. The research was conducted from January to June 2020 at Sekolah Dasar (SD) 1 Kedunglengkong, SD 1 Talakbroto, and SD Wates, Simo Sub-district, Boyolali Regency, Central Java and the Laboratory of Parasitology, Faculty of Medicine, Sebelas Maret University, Surakarta, Central Java, Indonesia.

This research used total sampling technique with subjects consisting of 132 students of SD 1 Kedunglengkong, SD 1 Talakbroto, and SD Wates from grades 1 to 6 in the 2019/ 2020 academic year who were willing to sign informed consent, fill out and collect questionnaires, and collect fecal samples. Before the research was conducted, the parents were notified and provided with the information regarding the research. The parents then filled out the informed consent and the clean and healthy living questionnaire. Student stool samples were collected on the following day. The I samples were then examined using the Kato Katz method at the Parasitology Laboratory of Faculty of Medicine, Sebelas Maret University. Data were presented in categorical form and analyzed using the chi square method. Statistical analysis was performed using SPSS ver. 23 for Windows. This study has obtained ethical clearance from the Dr. Moewardi General Regional Hospital Surakarta with a permit number 765/VI/HREC/2020.

\section{Results and Discussion}

\subsection{Results}

3.1.1 Characteristics of Subjects

Table 1 presents the characteristics of research subjects. The majority of the research subjects were female (55.0\%) aged 11 years old (22.7\%). Most students' 
parents are laborers (45.4\%). The results of fecal samples examination revealed that $11 \%$ of students were positively infected with STH. A large number of subjects, namely 83 respondents had poor behavior of clean and healthy living (63\%).

Table 2 shows that there is a significant relationship between STH infection with clean and healthy living behavior $(\mathrm{OR}=4.364 ; 95 \% \mathrm{Cl}=0.941-20.234 ; \mathrm{p}<0.05)$. More details can be seen on Table 2 .

Table 1. Characteristics of Research Subjects

\begin{tabular}{lcc}
\hline \multicolumn{1}{c}{ Characteristics } & $\mathbf{n}$ & $\%$ \\
\hline STH Infection & 15 & 11 \\
$\quad$ Positive & 117 & 89 \\
$\quad$ Negative & 59 & \\
Sex & 73 & 45 \\
Male & & 55 \\
Female & 4 & 3 \\
Age (Years old) & 12 & 9.1 \\
6 & 17 & 12.9 \\
7 & 22 & 16.7 \\
8 & 29 & 22 \\
9 & 30 & 22.7 \\
10 & 16 & 12.1 \\
11 & 2 & 1.5 \\
12 & & \\
13 & 3 & 2.3 \\
Parents' job & 1 & 0.8 \\
Civil servants & 5 & 3.8 \\
Cruise & 9 & 6.8 \\
Army/Police & 44 & 33.3 \\
General employees & 60 & 45.5 \\
Entrepreneur & 8 & 6.1 \\
Labor & 2 & 1.5 \\
Farmer & & \\
Village Office & 8 & 53 \\
STH Species & 5 & 33 \\
Ascaris lumbricoides & 1 & 7 \\
Trichuris trichiura & 1 & \\
Hookworm & & \\
Multiple infection & 49 & \\
Clean and Healthy Living & & \\
Behavior & & \\
Good lifestyle & & \\
Bad lifestyle & & \\
& &
\end{tabular}

Table 2. Bivariate Analysis Research

\begin{tabular}{|c|c|c|c|c|c|c|}
\hline \multirow{3}{*}{$\begin{array}{c}\text { STH } \\
\text { Infection }\end{array}$} & \multicolumn{4}{|c|}{ Clean and Healthy Living Behavior } & \multirow[t]{3}{*}{$P$ value } & \multirow[t]{3}{*}{ OR $(95 \% \mathrm{Cl})$} \\
\hline & & & & & & \\
\hline & $\mathbf{n}$ & $\%$ & $\mathbf{n}$ & $\%$ & & \\
\hline Pos & 13 & 15.7 & 2 & 4.1 & 0.043 & 4.364 \\
\hline Negative & 70 & 84.3 & 47 & 95.9 & & $(0.941-20.234)$ \\
\hline
\end{tabular}

\subsection{Discussion}

Based on the results of research conducted from 132 students, there were 15 students (11\%) positively infected by STH. The results of clean and healthy living behavior or Perilaku Hidup Bersih dan Sehat (PHBS) questionnaire revealed that most students were in the poor PHBS category. The results of the analysis showed that there is a significant relationship between clean healthy living behavior and STH infection. In 
accordance with the present results, previous studies such as one conducted in Hoima, Uganda have demonstrated that there is a significant relationship between poor hygiene, inadequate sanitation and irregular deworming with STH infection [24].

Students at Sekolah Dasar 1 Kedunglengkong, SD 1 Talakbroto, and SD Wates have the habit of going barefoot while playing and exercising. The school environment, close to area with open soil such as rice fields, grass fields and road access, which are often flooded with water, can be a factor for the transmission of STH infection [2,5]. Of these three primary schools, only SD 1 Kedunglengkong has handwashing facilities while SD 1 Talakbroto and SD Wates do not have one yet. This made it difficult for students to access handwashing facilities and develop handwashing habit. Among the three schools, none of them has placed handwashing soap in the school's bathroom. A previous study found that providing WASH (Water, Sanitation and Hygiene) that include a tap, a sink and soap in schools change students' WASH knowledge, attitudes and hygiene behavior, thus protecting them against diarrhea and STH illness [24].

Clean and healthy living behavior is a factor that affects the transmission of STH infection [7]. Clean and Healthy Living Behavior Behavior or Perilaku Hidup Bersih dan Sehat (PHBS) is practicing healthy behavior out of personal health awareness so that a person or family can prevent, mitigate, and protect themselves from disease [24,25]. Water quality, fecal disposal system, and hygiene habit (handwashing and wearing footwear) affect the incidence of STH infection [5]. Practising good hygiene measures (handwashing and wearing shoes when outside the house) are more likely to protect childrens and other family members from acquiring STH infection. Other essential hygiene measures washing hands before eating and after defecating, and washing fruits and vegetables before consumption [26,27].

The results of this study found that some students had poor hygiene and healthy living behavior due to the habit of not wearing footwear. STH infection or soil-borne worms are closely related to the habit of walking barefoot on contaminated soil. This habit can be a factor causing STH infection through skin penetration [9]. Children who are barefoot when they are outside the house are susceptible to Ascaris lumbricoides infection [28]. A previous study reported that preschool-age children and children who walk barefoot may be at an increased risk of STH burden [29].

The multifactorial condition which includes the economic level of the community, knowledge of cleanliness and health, as well as self-awareness to maintain cleanliness and health are factors that affect the behavior of clean and healthy living [21]. Children from low socio-economic status are generally unable to gain access to adequate sanitation thus affecting the efficacy of health improvement programs [33].

The results of this study are in line with research conducted on children of Moyudan elementary school in Sleman Regency which showed that there was a significant relationship between STH infection and the habit of handwashing before eating and after defecating, the habit of wearing footwear, and defecation habit [22]. Research conducted on coffee plantation workers in Jember also showed a significant relationship between clean and healthy living behavior and the incidence of STH infection [7]. An earlier study reported that the risk factors based on the transmission of intestinal parasites is related to poor sources of drinking water, hygiene practices, fecal disposal system, soslcio-economic status and the existence of wide variations of parasites within human communities [35].

However, the findings of the current study do not support the previous research conducted in Koto Tengah Padang Sub-district where no significant relationship was found between clean and healthy living behavior and STH infection [21]. The findings of this study are also contrary to a study conducted in the village of Suka,District Tigapanah Sub-district, North Sumatra where handwashing and using clean latrines lowered STH infections [2]. Interventions that promote hygiene education have been found to be effective in reducing helminth infections [31].

\section{Conclusion}

The results of the study showed that there is a significant relationship between Soiltransmitted Helminth (STH) infections with clean and healthy living behavior or Perilaku Hidup Bersih dan Sehat (PHBS). Further studies should be undertaken in order to closely examine the factors that influence clean and healthy lifestyle and STH infections. 


\section{References}

1. Menteri Kesehatan Republik Indonesia. Peraturan Menteri Kesehatan Republik Indonesia Nomor 15 Tahun 2017 Tentang Penanggulangan Cacingan. 2017;

2. Pasaribu AP, Alam A, Sembiring K, Pasaribu S, Setiabudi D. Prevalence and Risk Factors of Soil-Transmitted Helminthiasis Among School Children Living in An Agricultural Area of North Sumatera, Indonesia. BMC Public Health. 2019;19(1):1-8. doi: 10.1186/s12889-019-7397-6

3. Yuwono N, Husada D, Basuki S. Prevalence of Soil-Transmitted Helminthiasis Among Elementary Children in Sorong District, West Papua. Indones J Trop Infect Dis. 2019;7(4):86. doi: http://dx.doi.org/10.20473/ijtid.v7i4.7362

4. Rahmawati A. Hubungan Higiene Sanitasi dengan Infeksi Kecacingan pada Anak SD. Poltekkes Kemenkes Semarang. 2019;01(01):6-10. doi: https://doi.org/10.31983/jlm.v1i1.4924

5. Vaz Nery S, Pickering AJ, Abate E, Asmare A, Barrett L, Benjamin-Chung J, et al. The Role of Water, Sanitation and Hygiene Interventions in Reducing Soil-Transmitted Helminths: Interpreting The Evidence and Identifying Next Steps. Parasites and Vectors. 2019;12(1):1-8. doi: https://doi.org/10.1186/s13071-019-3532-6

6. Vaz Nery S, Clarke NE, Richardson A, Traub R, Mccarthy JS, Gray DJ, Et Al. Risk Factors For Infection with Soil-Transmitted Helminths During An Integrated Community Level Water, Sanitation, and Hygiene and Deworming Intervention in Timor-Leste. Int $J$ Parasitol. 2019;49(5):389-96. doi: https://doi.org/10.1016/j.ijpara.2018.12.006

7. Al-Muzaky AH, Hermansyah B, Suswati E, Armiyanti Y, Nurdian Y. Hubungan Perilaku Hidup Bersih dan Sehat Dengan Kejadian Infestasi Soil-Transmitted Helminths Pada Pekerja Perkebunan Kopi Sumber Wadung Kabupaten Jember. J Kedokt dan Kesehat Publ IIm Fak Kedokt Univ Sriwij. 2019;6(1):7-15. doi: https://doi.org/10.32539/JKK.v6i1.7233

8. Majorin F, Torondel B, Chan GKS, Clasen T. Interventions to Improve Disposal of Child Faeces For Preventing Diarrhoea and Soil-Transmitted Helminth Infection. Cochrane Database Syst Rev. 2019;2019(9). doi: 10.1002/14651858.CD011055.pub2

9. Paige SB, Friant S, Clech L, Malavé C, Kemigabo C, Obeti R, et al. Combining Footwear with Public Health Iconography to Prevent Soil-Transmitted Helminth Infections. Am J Trop Med Hyg. 2017;96(1):205-13. doi: 10.4269/ajtmh.15-0910.

10. Afroz S, Debsarma S, Dutta S, Rhaman MM, Mohsena M. Prevalence of Helminthic Infestations Among Bangladeshi Rural Children and Its Trend Since Mid-Seventies. IMC J Med Sci. 2019;13(1):004. doi: http://dx.doi.org/10.3329/imcjms.v13i1.42038

11. Moncayo AL, Lovato R, Cooper PJ. Soil-transmitted Helminth Infections and Nutritional Status in Ecuador: Findings From A National Survey and Implications For Control Strategies. BMJ Open. 2018;8(4):1-9. doi: http://dx.doi.org/10.1136/bmjopen-2017021319.

12. Guan M, Han B. Association Between Intestinal Worm Infection and Malnutrition Among Rural Children Aged 9-11 Years Old in Guizhou Province, China. BMC Public Health. 2019;19(1):1-11. doi: https://doi.org/10.1186/s12889-019-7538-y

13. de Gier B, Pita-Rodríguez GM, Campos-Ponce M, van de Bor M, Chamnan C, JuncoDíaz $R$, et al. Soil-transmitted Helminth Infections and Intestinal and Systemic Inflammation in Schoolchildren. Acta Trop. 2018;182:124-7. doi: https://doi.org/10.1016/j.actatropica.2018.02.028.

14. Aji DP, Garini A, Hermansyah H. Hubungan Infeksi Soil Transmitted Helminth Dengan Anemia Pada Siswa Sekolah Dasar di Kecamatan Gandus Kota Palembang Tahun 2016. Kesehat Palembang. 2017;12(1):59-62. doi: https://jurnal.poltekkespalembang.ac.id/index.php/JPP/article/view/16

15. Molla E, Mamo H. Soil-Transmitted Helminth Infections, Anemia and Undernutrition Among Schoolchildren in Yirgacheffee, South Ethiopia. BMC Res Notes. 2018;11(1):17. doi: https://doi.org/10.1186/s13104-018-3679-9.

16. Campbell SJ, Nery S V., D'Este CA, Gray DJ, McCarthy JS, Traub RJ, et al. Investigations Into The Association Between Soil-Transmitted Helminth Infections, Haemoglobin and Child Development Indices in Manufahi District, Timor-Leste. Parasites and Vectors. 2017;10(1):1-15. doi: https://doi.org/10.1186/s13071-017-2084-x 
17. Chaudhary S, Raj Subedi J. Comparative Prevalence of Intestinal Helminths in Satar and Chaudhary Communities of Birtamode Municipality, Jhapa, Nepal. Natl J Heal Sci. 2020;5(1):4-12. doi: http://dx.doi.org/10.21089/njhs.51.0004

18. Owada K, Nielsen M, Lau CL, Clements ACA, Yakob L, Soares Magalhães RJ. Measuring the Effect of Soil-Transmitted Helminth Infections on Cognitive Function in Children: Systematic Review and Critical Appraisal of Evidence. Adv Parasitol. 2017;98:1-37. doi: https://doi.org/10.1016/bs.apar.2017.05.002.

19. Pabalan N, Singian E, Tabangay L, Jarjanazi H, Boivin MJ, Ezeamama AE. SoilTransmitted Helminth Infection, Loss of Education and Cognitive Impairment in SchoolAged Children: A Systematic Review and Meta-Analysis. Vol. 12, PLoS Neglected Tropical Diseases. 2018. 1-31 p. doi: https://doi.org/10.1371/journal.pntd.0005523.

20. Oktaria S, Effendi EH, Indriatmi W, van Hees CLM, Thio HB, Sjamsoe-Daili ES. SoilTransmitted Helminth Infections and Leprosy: A Cross-Sectional Study of The Association Between Two Major Neglected Tropical Diseases in Indonesia. BMC Infect Dis. 2016;16(1):1-6. doi: http://dx.doi.org/10.1186/s12879-016-1593-0.

21. Kementerian Pendidikan dan Kebudayaan. DAFTAR SATUAN PENDIDIKAN (SEKOLAH) PER Kec. Ampel. 2020. https://referensi.data.kemdikbud.go.id/index11_sd.php?kode=030902\&level=3. Accessed on Nov 272020.

22. Pemerintah Desa Simo. Desa Simo (Kecamatan Simo Kabupaten Boyolali). https://simo.desa.id/index.php. Accessed on Nov 272020.

23. Dinas Kesehatan Kabupaten Boyolali. Kabupaten Boyolali Tahun 2018. 2018;

24. Ojja S, Kisaka S, Ediau M, Tuhebwe D, Kisakye AN, Halage AA, et al. Prevalence, Intensity and Factors Associated with Soil-Transmitted Helminths Infections Among Preschool-Age Children in Hoima District, Rural Western Uganda. BMC Infect Dis. 2018;18(1):1-12. doi: https://doi.org/10.1186/s12879-018-3289-0

25. McMichael C. Water, Sanitation And Hygiene (WASH) in Schools in Low-Income Countries: A Review of evidence of impact. Int $J$ Environ Res Public Health. 2019;16(3):1-21. doi: https://doi.org/10.3390/ijerph16030359

26. Sinaga ER, Resi EM, Wanti W. Personal Hygiene and Worm Eggs at Pupils Nail in Kupang City, Indonesia. Int $J$ Public Heal Sci. 2016;5(3):320. doi: https://dx.doi.org/10.11591/ijphs.v5i3.4802

27. Puspita WL, Khayan K, Hariyadi D, Anwar T, Wardoyo S, Ihsan BM. Health Education to Reduce Helminthiasis: Deficits in Diets in Children and Achievement of Students of Elementary Schools at Pontianak, West Kalimantan. J Parasitol Res. 2020;2020. doi: https://doi.org/10.1155/2020/4846102

28. Nasr NA, Al-Mekhlafi HM, Ahmed A, Roslan MA, Bulgiba A. Towards An Effective Control Programme of Soil-Transmitted Helminth Infections Among Orang Asli in Rural Malaysia. Part 1: Prevalence and Associated Key Factors. Parasites and Vectors. 2019;6(1):1-12. doi: https://doi.org/10.1186/1756-3305-6-27

29. Makata K, Kinung'hi S, Hansen C, Ayieko P, Sichalwe S, McHaro O, et al. Hand Hygiene Intervention to Optimize Helminth Infection Control: Design and Baseline Results of Mikono Safi-An Ongoing School-Based Cluster-Randomised Controlled Trial in NW Tanzania. PLoS One [Internet]. 2020;15(12 December):1-20. Available from: http://dx.doi.org/10.1371/journal.pone.0242240.

doi: https://doi.org/10.1371/journal.pone.0242240

30. Suryantari S, Satyarsa A, Hartawan I, Yana K SI. Prevalence, Intensity and Risk Factors of Soil Transmitted Helminths Infections among Elementary School Students in Ngis Village, Karangasem District, Bali. Indones J Trop Infect Dis. 2019;7(6):137-43. doi: http://dx.doi.org/10.20473/ijtid.v7i6.9952

31. Errea RA, Vasquez-Rios G, Calderon ML, Siu D, Duque KR, Juarez LH, et al. SoilTransmitted Helminthiasis in Children From A Rural Community Taking Part in A Periodic Deworming Program in the Peruvian Amazon. Am J Trop Med Hyg. 2019;101(3):636-40. doi: https://doi.org/10.4269/ajtmh.18-1011

32. Nugraha TI, Semiarty R, Irawati N. Hubungan Sanitasi Lingkungan dan Personal Hygiene Dengan Infeksi Soil Transmitted Helminths (STH) pada Anak Usia Sekolah Di Kecamatan Koto Tangah Kota Padang. J Kesehat Andalas. 2019;8(3):590. doi: https://doi.org/10.25077/jka.v8i3.1046. 
33. Yufiarti Y, Edwita, Suharti. Health Promotion Program (JUMSIH); To Enhance Children's Clean and Healthy Living Knowledge. JPUD - J Pendidik Usia Dini. 2019;13(2):341-55. doi: https://doi.org/10.21009/JPUD.132.10

34. Wulandari A, Saleh I, Silviana. Factors Related To Worm Infection (Soil Transmitted Helminth) And Learning Achievement Among Elementary Students At Work Area Of Puskesmas Punggur. openjurnal.unmuhpnk. 2017; doi: http://dx.doi.org/10.20473/ijtid.v7i6.9952

35. Tabi ESB, Eyong EM, Akum EA, Löve J, Cumber SN. Soil-Transmitted Helminth Infection in the Tiko Health District, South West Region of Cameroon: A PostIntervention Survey on Prevalence and Intensity of Infection Among Primary School Children. Pan Afr Med J. 2018;30:1-9. doi: https://dx.doi.org/10.11604\%2Fpamj.2018.30.74.15676 